Relations industrielles

Industrial Relations

\title{
Practical Cases
}

\section{Donat Quimper}

Volume 2, numéro 6, février 1947

URI : https://id.erudit.org/iderudit/1023864ar

DOI : https://doi.org/10.7202/1023864ar

Aller au sommaire du numéro

Éditeur(s)

Département des relations industrielles de l’Université Laval

ISSN

0034-379X (imprimé)

1703-8138 (numérique)

Découvrir la revue

Citer cet article

Quimper, D. (1947). Practical Cases. Relations industrielles / Industrial Relations, 2(6), 7-7. https://doi.org/10.7202/1023864ar

Tous droits réservés @ Département des relations industrielles de l’Université Laval, 1947
Ce document est protégé par la loi sur le droit d'auteur. L’utilisation des services d'Érudit (y compris la reproduction) est assujettie à sa politique d'utilisation que vous pouvez consulter en ligne.

https://apropos.erudit.org/fr/usagers/politique-dutilisation/ 


\section{PRACTICAL CASES}

Can an employer validly impose on latecomers amongst his employees a fine equivalent to one quarter of an hour's pay for each five minutes' delay in coming to work?

\section{Could you also tell me by what criterion the validity} of a contractual provision may be ascertained?

The validity of a provision may be established by a criterion which is to be found in the two following sections of the Civil Code:

A-Section 13: "No one can, by private agreement, validly contravene the laws of public order and good morals".

B-Section 14: "Prohibitive laws import nullity although such nullity be not therein expressed."

Public order is that upon the maintainance of which the existence of society depends. Indeed, the maintainance of public order is the very purpose of the enactment of Constitutional, Administrative and Criminal law, the laws concerning family rights, the status or capacity of persons, the prevention of fraud, the protection of individuals, in short, Public Law as a whole.

The term good morals means monals consistent with Christian ethics.

Prohibitive laws imply a prohibition; therefore, in virtue of such laws, certain things are forbidden. Now, section 14 of the Civil Code deals with the consequenses of the violation of such laws by decreeing that anything which contravenes their provisions is null, even though such nullity be not explicitly mentioned in their wording.

From the foregoing principles it follows that the criterion in question comprises three essential items which must be equally taken into account in appraising a given provision.

Is such provision contrary to public order? Is it inconsistent with good morals? Is it contrary to a prohibitive law? Obviously, if "no" is the answer in each case, the provision in question is valid. On the other hand, if "yes" is the answer to even just one of these questions, the provision being examined must be deemed illegal.

In this particular case, it is a question of knowing whether or not an emyloyer has the right to penalize those amongst his employees who come in late to work by making them lose a certain amount of time.

In fact, it seems to us that such a penalty is by no means contrary to public order, inasmuch as its application does not involve a departure from the wage rates fixed by Decree or prescribed by the Ordinances of the Minimum Wage Commission. It is merely a disciplinary measure intended to ensure punctuality. Besides, who would deny that in a large industry, where rationalization has set up work in series, an employer would sustain a considerable loss through an employee's mere delay in coming to work. Hundreds of operations could thus be impaired...

Would such a penalty be inconsistent with good morals? No! unless it were imposed with such exaggeration that it would cease to be a mere disciplinary measure and become equival:nt to robbery, i.e. a means of exploiting the worker.

However, we would advise the employer not to "apply" such penalties too mercilessly nor too generally so as to avoid the possibility of injustice in certain particular cases. Sufficiently justified delays in coming to work should be generously overlooked.

Finally, to the best of our knowledge, there exists no law forbidding employers to penalize latecomers. Consequently, since we have given a negative answer to each of our three-questions, we may infer that the manner in which this employer treats the latecomers amongst his employees is by no means unlawful as long as he applies such penalties within reasonable limits and does not profit by them to violate the provisions of a Decree or depart from the minimum wage rates fixed by the Ordinances. Nevertheless, as concerns sound industrial relations, could it be said that such a disciplinary measure is as wise as effective? It would be preferable if the fines collected were placed in a fund specially intended to promote the organizing of social services within the enterprise.

Donat QUIMPER

\section{FAUT-IL PREVENIR LE PATRON}

(Suite à la page 8)

Que leur union va changer cette situation, le patron le sent bien et il est normal que ses premières impressions ne soient guère sympathiques. Mais le patron intelligent réfléchit et se rend vite compte qu'il gagnera à ce changement. Il assurera à son entreprise la collaboration organisée de son personnel, qui, secouant l'état de sujétion où il était, accroît sa valeur humaine et ses possibilités de rendement. L'expérience ne tardera pas à lui montrer que les syndiqués les plus fervents forment l'élite de sa main-d'oeuvre. Cependant, la première réaction du patron est toujours à craindre car elle peut pousser à des attitudes hostiles qui menacent la vie du syndicat naissant.

Quant aux demandes extravagantes, le patron a toujours la liberté de les discuter et de les refuser. Mais en accédant à une juste requête de ses employés, loin de se diminuer, il pose un geste qui sera beaucoup plus apprécié que toute libéralité teintée d'un certain paternalisme orgueilleux: "Je donne parce que je veux, et non parce qu'ils me demandent ».

Concluons: dans la quasi généralité des cas, il est normal que les ouvriers ne préviennent pas leur patron de leur intention de s'unir. En se groupant ils ne font qu'user de leur liberté d'association que le droit naturel et la loi leur garantissent. (Loi des relations ouvrières, art. 3,20,21,22). L'employeur qui n'a pas été averti peut ne •pas aimer ce silence, mais il a tort de croire que ses travailleurs ou les organisateurs d'unions lui jouent dans le dos. Il lui est beaucoup plus profitable de se ménager dès le début des relations cordiales avec le syndicat de ses employés.

OMER - Genest 